\title{
Mitogenic and anti-apoptotic activity of insulin on bovine embryos produced in vitro
}

\author{
R. Augustin ${ }^{*}$, P. Pocar ${ }^{1}$, C. Wrenzycki ${ }^{2}$, H. Niemann ${ }^{2}$ and B. Fischer ${ }^{1}$ \\ ${ }^{1}$ Department of Anatomy and Cell Biology, Martin Luther University Faculty of Medicine, Halle (Saale), \\ Germany; and ${ }^{2}$ Department of Biotechnology, Institut für Tierzucht (FAL), Neustadt, Germany
}

\begin{abstract}
Insulin improves development of mammalian preimplantation embryos and, in addition to the regulation of glucose transport, it exerts mitogenic and anti-apoptotic activities. The expression of glucose transporters (Glut) mediating the uptake of this essential energy substrate is critical for embryo survival. An impaired expression of Glut leads to an increase in apoptosis at the blastocyst stage and involves Bax. The various effects of insulin were unravelled by supplementing the in vitro culture medium with insulin $\left(1.7 \mu \mathrm{mol} \mathrm{I}^{-1}\right)$ and (i) the rates of cleavage and blastocyst development were recorded; (ii) mitogenic activity was studied by determining the total number of blastocyst cells and the ratio between trophectoderm and inner cell mass (ICM) cells; (iii) the frequency of apoptosis in blastocysts was determined by the TdT-mediated dUTP nick-end labelling (TUNEL) assay and by quantification of the relative amounts of mRNA for Bax and Bcl- $\mathrm{X}_{\mathrm{L}}$; and (iv) expression for Glut1,
\end{abstract}

Glut3 and Glut8 transcripts was compared between embryos cultured in the presence or absence of insulin. Insulin increased rates of cleavage $(81.2 \pm 2.2$ (control) to $86.0 \pm 2.5$ ) and blastocyst development $(24.7 \pm 1.9$ to $31.3 \pm 1.2)$, and number of blastocyst cells $(123.7 \pm 6.0$ to $146.3 \pm 6.6)$; the increase in the number of blastocyst cells was due to a significantly higher number of trophectoderm cells $(82.3 \pm 5.0$ versus $100.3 \pm 5.5$ ). Blastocysts derived from cultures supplemented with insulin showed a significant decrease in apoptosis as determined by the TUNEL assay $(14.8 \pm 0.9$ to $12.2 \pm 0.7)$. No effects of insulin on the mRNA expression of Glut isoforms and $\mathrm{Bax}$ and $\mathrm{BCl}-\mathrm{X}_{\mathrm{L}}$ were found. These results demonstrate that the mitogenic and anti-apoptotic effects of insulin on bovine preimplantation embryos did not correlate with changes in the amounts of mRNA for the glucose transporter isoforms Glut 1, -3 and -8, or transcripts for Bax and $\mathrm{BCl}-\mathrm{X}_{\mathrm{L}}$.

\section{Introduction}

Despite significant progress in the production of embryos in vitro (IVP), in vitro embryos differ from embryos produced in vivo with regard to morphology, metabolism (Khurana and Niemann, 2000) and gene expression (Niemann and Wrenzycki, 2000). Advancements in the understanding of the development of embryos produced in vitro have been achieved using defined culture media that enable the specific effects of a variety of media supplements, such as growth factors including insulin, to be studied (Kaye and Harvey, 1995; Diaz-Cueto and Gerton, 2001).

As a potent anabolic hormone in differentiated cells (for a review, see Saltiel and Kahn, 2001), insulin stimulates glucose (Summers et al., 1999) and amino acid transport, and RNA, protein and glycogen synthesis (McGowan et al., 1995), and has mitogenic and

*Present address: Department of Obstetrics and Gynecology, 4911 Barnes-Jewish Hospital Plaza Campus Box 8064, St Louis, MO 63110, USA

Email: augustinr@msnotes.wustl.edu anti-apoptotic properties (Alessi and Cohen, 1998; Downward, 1998; Dalle et al., 2001). Studies in preimplantation embryos demonstrated improved embryo development after supplementation of culture media with insulin and insulin-like growth factor I (IGF-I) (mouse: Harvey and Kaye, 1990; Rao et al., 1990; Gardner and Kaye, 1991; Dunglison and Kaye, 1993; Heyner, 1997; rabbit: Herrler et al., 1998; cow: Matsui et al., 1995a; pig: Lewis et al., 1992; human: Spanos et al., 2000). Similar to differentiated cells, insulin increased glucose uptake, stimulated RNA and protein synthesis (Harvey and Kaye, 1988, 1991; Lewis et al., 1992; Dunglison and Kaye, 1993), and had mitogenic and anti-apoptotic activities in murine and rabbit embryos (Harvey and Kaye, 1990; Herrler et al., 1998). Experiments performed in vivo have shown that insulin improved rates of embryo development and pregnancy in diabetic animals (mouse: Diamond et al., 1989; Moley et al., 1991; rat: De Hertogh et al., 1992), rescuing embryos from the detrimental effects of maternal hyperglycaemia. However, the exact mechanism by which insulin influences this broad range of developmental effects in preimplantation embryos is not clear. 
Glucose is an essential energy substrate for development of mammalian blastocysts (mouse: Chatot et al., 1994; Martin and Leese, 1995; Biggers and McGinnis, 2001; sheep: McGinnis and Youngs, 1992; pig: Hagen et al., 1991; cow: Renard et al., 1980; Dorland et al., 1992; Brackett et al., 1997; Iwata et al., 1998). Glucose also becomes the predominant energy source after activation of the bovine embryonic genome (Javed and Wright, 1991; Khurana and Niemann, 2000). Glucose transport across plasma membranes is mediated by an extended family of sugar transport facilitators (Glut) (Joost and Thorens, 2001; Joost et al., 2002). The different Glut isoforms are characterized by their tissue or cell-specific expression, substrate specificity and kinetics of transport. Preimplantation embryos express different Glut isoforms (Pantaleon and Kaye, 1996, 1998; Carayannopoulos et al., 2000; Augustin et al., 2001). Normal glucose uptake by blastocysts is accomplished by Glut3 and Glut1 (Pantaleon and Kaye, 1996, 1998). Expression of Glut8 was recently reported to be responsive to insulin in blastocysts (Carayannopoulos et al., 2000). Glut3 and Glut8 are critical for development of mouse blastocysts (Pantaleon et al., 1997; Carayannopoulos et al., 2000; Pinto et al., 2002). The process of controlled cell death occurs, as a physiological phenomenon, in early embryo development (for a review, see Hardy, 1999). However, different in vitro culture conditions affect the rate of apoptosis in preimplantation embryos (Byrne et al., 1999). Impaired glucose transport can increase apoptosis in cell lines (Kan et al., 1994), as well as in preimplantation embryos, of rats (Leunda-Casi et al., 2002) and mice (Moley et al., 1998a). Exposure of mouse preimplantation embryos to high glucose results in downregulation of Glut expression (Moley et al., 1998b) and increased apoptosis (Moley et al., 1998a). Apoptosis in embryos induced by high glucose is Bax dependent (Moley et al., 1998a) and in vivo and in vitro mouse and rat experimental models for maternal preconceptional diabetes have shown that it can be reversed in part by insulin treatment (Pampfer, 2000). These data indicate a link between insulin, glucose transport or metabolism and apoptosis in developing embryos.

Expression of receptors and ligands of the insulin-IGF family (IR, IGF-IR, IGF-IIR (Schultz et al., 1992; Yaseen et al., 2001), insulin-like growth factor binding proteins (IGFBPs: Winger et al., 1997; Prelle et al., 2001) and glucose transporters, including the insulin responsive isoforms Glut4 and Glut8 (Navarrete Santos et al., 2000; Augustin et al., 2001), in bovine preimplantation embryos is indicative of the presence of an active insulin-IGFI signalling pathway, and points to glucose transporters as a possible link. This contention prompted the present authors to investigate the effects of insulin on bovine preimplantation embryos with respect to its mitogenic and anti-apoptotic activities, and in relation to expression of glucose transporters. Bovine embryos produced in vitro were exposed to insulin throughout the culture period and several factors were examined: (i) rates of cleavage and blastocyst development, total number of blastocyst cells and the ratio of trophectoderm to inner cell mass (ICM) cells; (ii) apoptosis using the TUNEL assay and determination of the relative amounts of mRNA for the pro- and anti-apoptotic genes $B a x$ and $B C l-X_{\mathrm{L}}$; and (iii) $\mathrm{mRNA}$ expression of the glucose transporter isoforms Glut1, Glut3 and Glut8.

\section{Materials and Methods}

In vitro production (IVP) of bovine embryos

Unless otherwise stated, the biochemicals used for IVP of bovine embryos were purchased from Sigma (St Louis, MO). Ovaries were collected from a local abattoir and were transported to the laboratory within $2 \mathrm{~h}$ in Dulbecco's phosphate buffered saline (DPBS), supplemented with 10000 iu penicillin, $10 \mathrm{mg}$ streptomycin and $250 \mathrm{mg}$ amphotericin $\mathrm{BI}^{-1}$, maintained at $32-34^{\circ} \mathrm{C}$. Cumulus-oocyte complexes (COCs) were collected from ovarian follicles by slicing with razor blades (Eckert and Niemann, 1995) in modified DPBS with $2 \mathrm{iu}$ heparin and $0.1 \%(\mathrm{w} / \mathrm{v})$ BSA Fraction V. COCs were selected in Hepes buffered $\left(25 \mathrm{mmol} \mathrm{I}^{-1}\right)$ TCM199 and only COCs with at least three layers of compact cumulus cells and a homogeneous cytoplasm were considered to be suitable for maturation and were used for the following experiments. Maturation medium was TCM199, supplemented with $0.68 \mathrm{mmol}$ Lglutamine I ${ }^{-1}, 25 \mathrm{mmol} \mathrm{NaHCO}_{3} \mathrm{I}^{-1}, 10 \%$ fetal calf serum, 10 iu eCG ml-1 and 5 iu hCG ml-1 (Suigonan; Intervet, Wiesbaden) and $1 \mu \mathrm{g}$ oestradiol $\mathrm{ml}^{-1}$. Groups of 30-40 COCs were matured in $500 \mu$ l maturation medium. Incubation was performed for $24 \mathrm{~h}$ in fourwell dishes (Nunc, Roskilde) at $39^{\circ} \mathrm{C}$ in a humidified atmosphere of $5 \% \mathrm{CO}_{2}$ in air. After maturation, the COCs were washed twice in Tyrode's albumin lactate pyruvate medium (TALP; Bavister et al., 1983) supplemented with $0.6 \%(\mathrm{w} / \mathrm{v})$ fatty acid free BSA and $20 \mathrm{mmol}$ Hepes $\mathrm{I}^{-1}$ (H-TALP,) and groups of 25-35 COCs were transferred to $300 \mu$ l fertilization medium (TALP medium supplemented with $0.6 \%(\mathrm{w} / \mathrm{v})$ fatty acid free BSA, $10 \mathrm{mg}$ heparin $\mathrm{ml}^{-1}, 20 \mathrm{mmol}$ penicillamine $\mathrm{I}^{-1}, 1 \mathrm{mmol}$ adrenalin $\mathrm{I}^{-1}$ and $100 \mathrm{mmol}$ hypotaurine $\mathrm{I}^{-1}$ (Bavister, 1989)). A straw containing frozen spermatozoa was thawed in a waterbath at $34^{\circ} \mathrm{C}$ for $1 \mathrm{~min}$, and the cells were layered on to a $45-90 \%(\mathrm{v} / \mathrm{v})$ Percoll gradient in modified TALP medium. After centrifugation for $30 \mathrm{~min}$ at $600 \mathrm{~g}$, the resulting motile sperm fraction was washed once in TALP medium, counted and diluted to a final concentration of $1 \times 10^{6}$ spermatozoa $\mathrm{ml}^{-1}$ in fertilization medium. Co-incubation of oocytes and spermatozoa was performed in four-well dishes for $18 \mathrm{~h}$ at $39^{\circ} \mathrm{C}$ in a humidified atmosphere of $5 \% \mathrm{CO}_{2}$ in air.

Presumptive zygotes were denuded from cumulus cells by vortexing in H-TALP for 3 min. After washing 
in synthetic oviductal fluid (SOF; Tervit et al., 1972), groups of 8-10 embryos were placed in $30 \mu \mathrm{l}$ droplets of SOF medium under oil supplemented with $0.8 \%$ $(\mathrm{w} / \mathrm{v})$ BSA, glutamine $\left(0.33 \mathrm{mmol} \mathrm{I}^{-1}\right)$, and essential and non-essential amino acids. Embryos were cultured in an incubation chamber (Billups Rothenberg, del Mar, CA) under $5 \% \mathrm{O}_{2}, 5 \% \mathrm{CO}_{2}$ and $90 \% \mathrm{~N}_{2}$ at $39^{\circ} \mathrm{C}$. For insulin-supplemented in vitro culture, insulin was used at a concentration of $1.7 \mu \mathrm{mol} \mathrm{I}^{-1}$ in SOF. Presumptive zygotes had been washed in the same medium before they were placed into microdroplets for culture. This insulin concentration was selected on the basis of previous results describing an increased number of blastocyst cells and proportion of morulae grown in $\mathrm{mSOF}+$ polyvinylalcohol (PVA) supplemented with 1 mmol glucose $I^{-1}$ and amino acids (Matsui et al., 1995a). Analyses were performed at the end of culture at $186 \mathrm{~h}$ after insemination.

\section{Differential staining of blastocysts: determination of trophectoderm cell:ICM ratio}

The differential staining of ICM and trophectoderm cells was performed according to Thouas et al. (2001) with minor modifications. In brief, expanded blastocysts were incubated in $500 \mu \mathrm{l}$ Hepes-buffered SOF medium with $1 \%(\mathrm{v} / \mathrm{v})$ Triton-X100 and $100 \mu \mathrm{g}$ propidium iodide $\mathrm{ml}^{-1}$ for $30 \mathrm{~s}$ by carefully moving the embryos by pipetting to ensure equal permeabilization of the trophectoderm cells. Immediately afterwards, the embryos were transferred into $500 \mu \mathrm{l}$ fixation medium consisting of $100 \%$ ethanol and $25 \mu \mathrm{g} \mathrm{ml}$ of Hoechst 33258 , and were incubated for $20 \mathrm{~min}$ at room temperature $\left(21^{\circ} \mathrm{C}\right)$. The blastocysts were mounted directly in glycerol droplets on to a microscope slide and flattened gently with a coverslip using silicone as a spacer. Samples were examined under a Nikon Diaphot microscope equipped with epifluorescence.

\section{TUNEL assay}

The embryos were washed three times in PBS supplemented with PVA and fixed in 4\% (w/v) PBS-buffered paraformaldehyde (PFA) for $20 \mathrm{~min}$. The embryos were incubated for $10 \mathrm{~min}$ in $0.5 \%(\mathrm{v} / \mathrm{v})$ Triton-X100 in PBS for membrane permeabilization. After washing the embryos in PBS, the TdT-mediated dUTP nick-end labelling (TUNEL) assay was performed according to the users' manual (TUNEL apoptosis detection kit; Boehringer Mannheim, Mannheim). In brief, the embryos were incubated for $1 \mathrm{~h}$ at $37^{\circ} \mathrm{C}$ in $30 \mu \mathrm{l}$ droplets of the TUNEL reaction mixture under oil. The reaction was stopped by transferring the blastocysts into PBS supplemented with BSA $(0.5 \%(\mathrm{w} / \mathrm{v}))$ for $10 \mathrm{~min}$ in the dark. The nuclei were stained with Hoechst $\left(10 \mu \mathrm{g} \mathrm{ml}^{-1}\right.$ diluted in $2.3 \%(\mathrm{w} / \mathrm{v})$ sodium citrate solution) and the embryos were mounted in glycerol as described for the differential staining procedure. Fixed blastocysts were treated with DNAse ( $5 \mu \mathrm{ml}^{-1}$ in cacodylate buffer) for $1 \mathrm{~h}$ at $37^{\circ} \mathrm{C}$ before the TUNEL reaction as positive controls. The specificity of the TUNEL assay was verified by omitting the TUNEL reagent as described in the manufacturer's instructions. Samples were examined under a Nikon Diaphot microscope equipped with epifluorescence and apoptosis was determined as the percentage of apoptotic bodies out of the total number of cells.

\section{Gene expression analysis: $\operatorname{Poly}(A)+R N A$ extraction and} semiquantitative $R T-P C R$

Poly $(A)^{+}$RNA from single blastocysts was extracted as described by Wrenzycki et al. (1999) and Augustin et al. (2001) using the Dynabeads mRNA direct $\mathrm{Kit}^{\circledR}$. Single blastocysts were lysed for $10 \mathrm{~min}$ in $20 \mu \mathrm{l}$ lysis/binding buffer $\left(0.1\right.$ mol Tris- $-\mathrm{HCl} \mathrm{I}^{-1}, \mathrm{pH} 7.5 ; 0.5 \mathrm{~mol} \mathrm{LiCl} \mathrm{I}^{-1}$; $10 \mathrm{mmol}^{\mathrm{EDTA} \mathrm{I}}{ }^{-1}, \mathrm{pH}$ 8.0; $1 \%$ (w/v) lithium dodecylsulphate (LiDS); 5 mmol dithiothreitol $\mathrm{I}^{-1}$ ). As a control to monitor the efficiency of mRNA extraction, $0.1 \mathrm{pg}$ rabbit globin mRNA (Invitrogen, Karlsruhe) was included in each sample as an exogenous standard. An aliquot $(5 \mu \mathrm{l})$ of prewashed Dynabeads oligo (dT)25 ${ }^{\circledR}$ was added and after $5 \mathrm{~min}$ of hybridization, the beads were separated from the lysis buffer using the Dynal ${ }^{\circledR}$ magnetic separator. The beads were washed once with $30 \mu \mathrm{l}$ buffer A $\left(10 \mathrm{mmol}\right.$ Tris- $\mathrm{HCl} \mathrm{I}{ }^{-1}, \mathrm{pH} 7.5 ; 0.15 \mathrm{~mol}$ $\left.\mathrm{LiCl} \mathrm{I}^{-1} ; 1 \mathrm{mmol} \mathrm{EDTA} \mathrm{I}^{-1} ; 0.1 \% \mathrm{LiDS}\right)$ and twice in the same volume with buffer $\mathrm{B}\left(10 \mathrm{mmol}\right.$ Tris- $\mathrm{HCl} \mathrm{I}{ }^{-1}$, $\mathrm{pH} 7.5 ; 0.15 \mathrm{mmol} \mathrm{LiCl} \mathrm{I}^{-1} ; 1 \mathrm{mmol}$ EDTA I ${ }^{-1}$ ). The poly $(A)^{+}$RNA was eluted from the beads with $11 \mu \mathrm{l}$ diethylpyrocarbonate-treated water and incubated at $65^{\circ} \mathrm{C}$ for $2 \mathrm{~min}$. The resulting poly $(\mathrm{A})^{+} \mathrm{RNA}$ was reversetranscribed in a total volume of $20 \mu \mathrm{l}$ using $2.5 \mathrm{mmol}$ random hexamer primers $\mathrm{I}^{-1}, 10 \times \mathrm{PCR}$ buffer, $20 \mathrm{iu}$ RNAse inhibitor, 50 iu MuLV reverse transcriptase (Perkin Elmer, Weiterstadt), $5 \mathrm{mmol} \mathrm{MgCl}_{2} \mathrm{I}^{-1}$ and $1 \mathrm{mmol}$ each $d N T P I^{-1}$. The reverse transcription reaction was performed by incubating the samples for $10 \mathrm{~min}$ at $25^{\circ} \mathrm{C}$, for $1 \mathrm{~h}$ at $42^{\circ} \mathrm{C}$ and $5 \mathrm{~min}$ at $99^{\circ} \mathrm{C}$. Samples were overlaid with oil to prevent evaporation during the last incubation step. Possible carryover of genomic DNA during the extraction process was controlled by the use of exon-intron spanning BCl-X PCR primers. On the basis of the human Bcl-X sequence the PCR primer pair matches exons 2 and 4 of the human gene (Z23115, Z23116) and results in the amplification of a $505 \mathrm{bp}$ and a $316 \mathrm{bp}$ fragment that correspond to the BCl$X_{L}$ and $B C l-X_{S}$ isoforms, respectively. PCR amplification of the blastocyst cDNA was performed as described by Augustin et al. (2001). For each gene, the primer combinations, the expected size of the amplification product, the number of cycles and the amount of cDNA used to determine relative mRNA expression in the linear range of the PCR are shown (Table 1). As a result of 
Table 1. Primer combinations, size of amplification product, number of PCR cycles and amounts of cDNA used for semi-quantitative RT-PCR

\begin{tabular}{|c|c|c|c|c|c|}
\hline Gene & Primer sequence $5^{\prime}-3^{\prime}$ & Number of PCR cycles & cDNA in embryo equivalent & Product size $(b p)$ & Accession no. (EMBL) \\
\hline \multirow[t]{2}{*}{ Actin } & TGAACCCTAAGGCCAACCGTG & \multirow[t]{2}{*}{28} & \multirow[t]{2}{*}{$1 / 20$} & \multirow[t]{2}{*}{268} & K00622 \\
\hline & TGTAGCCACGCTCGGTCAGG & & & & ВC016624 \\
\hline \multirow[t]{2}{*}{ Glut1 } & AGCGTCATCTTCATCCСАGC & \multirow[t]{2}{*}{34} & \multirow[t]{2}{*}{$2 / 20$} & \multirow[t]{2}{*}{544} & \multirow[t]{2}{*}{ M60448 } \\
\hline & CCACAATGCTCAGGTAGGAC & & & & \\
\hline \multirow[t]{2}{*}{ Glut3 } & ATGGCAGTGGCTGGTTGTTC & \multirow[t]{2}{*}{38} & \multirow[t]{2}{*}{$4 / 20$} & \multirow[t]{2}{*}{508} & \multirow[t]{2}{*}{ AF308829 } \\
\hline & GСТССТСАTGTCAGAGАTСТTC & & & & \\
\hline \multirow[t]{2}{*}{ Glut8 } & GСТССТСАТGTCAGAGАTСTTC & \multirow[t]{2}{*}{34} & \multirow[t]{2}{*}{$2 / 20$} & \multirow[t]{2}{*}{235} & \multirow[t]{2}{*}{ AF321324 } \\
\hline & GGCTGTGATTTGTTCCAGAGTC & & & & \\
\hline \multirow[t]{2}{*}{ Bax } & TGCTTCAGGGTTTCATCCAG & \multirow[t]{2}{*}{32} & \multirow[t]{2}{*}{$2 / 20$} & \multirow[t]{2}{*}{427} & \multirow[t]{2}{*}{ U92569 } \\
\hline & GTGTCCCAAAGTAGGAGAGG & & & & \\
\hline \multirow[t]{2}{*}{$\mathrm{BCl}-\mathrm{X}_{\mathrm{L}}$} & GGATAGCCСTGCTGTGAATGG & \multirow[t]{2}{*}{32} & \multirow[t]{2}{*}{$2 / 20$} & \multirow[t]{2}{*}{505} & \multirow[t]{2}{*}{ AF245489 } \\
\hline & TGAGCCCAGCAGAACCACAC & & & & \\
\hline
\end{tabular}

its low expression, transcripts of the insulin-regulated Glut4 were not quantified (Augustin et al., 2001). In total, 18 embryos per group from at least three different culture experiments were used for the semiquantitative RT-PCR. Two expanded blastocysts for the control and the insulin group were processed in parallel for RNA extraction, RT-PCR and agarose gel electrophoresis, and were considered as a single assay. The effect of the assay was included as a factor in the two-way ANOVA statistical analysis. As the total number of blastocyst cells was found to be significantly different between the two groups, the housekeeping gene actin (the endogenous standard) rather than the exogenous control globin was used to standardize gene expression. Although actin mRNA expression varies during embryo development (Robert et al., 2002), this housekeeping gene is an accepted standard to quantify gene expression at the blastocyst stage (Lonergan et al., 2000; Prelle et al., 2001). The PCR products were analysed by agarose gel electrophoresis using a digital gel documentation system (Bioprint; LTF-Labortechnik, Wasserburg) and relative amounts were determined as absorbance and analysed using the Bio-1-D program (LTF).

\section{Statistical analysis}

The rates of cleavage and blastocyst development were evaluated by the chi-squared test. The number of cells, the index of apoptosis and the data for mRNA expression were compared between the two groups using the SPSS 10.0 software package applying the two-way ANOVA. For comparison of the number of blastocyst cells and the apoptotic index between the two groups, the effect of the independent culture experiments (replicate) was included as the second factor in the analysis. For analysis of mRNA expression, the effect of the assay was tested as the second factor. Data are presented as mean \pm standard error of the means (SEM) and the level of significance was $P<0.05$.
Table 2. Effects of insulin on embryo development and number of blastocyst cells

\begin{tabular}{lcr}
\hline & Control & \multicolumn{1}{c}{$\begin{array}{c}\text { Insulin } \\
\text { supplementation }\end{array}$} \\
\hline Total number of oocytes & 484 & 527 \\
Cleavage (\% of oocytes) & $81.2 \pm 2.2^{\mathrm{a}}$ & $86.0 \pm 2.5^{\mathrm{b}}$ \\
Day 7 blastocysts (\% of oocytes) & $22.8 \pm 2.1^{\mathrm{a}}$ & $30.4 \pm 1.7^{\mathrm{b}}$ \\
Number of blastocyst cells & $123.7 \pm 6.0^{\mathrm{a}}$ & $146.3 \pm 6.6^{\mathrm{b}}$ \\
Ratio of trophectoderm : inner & & \\
$\quad$ cell mass (ICM) cells & $2.0 \pm 0.1^{\mathrm{a}}$ & $2.3 \pm 0.1^{\mathrm{a}}$ \\
Number of trophectoderm cells & $82.4 \pm 5.0^{\mathrm{a}}$ & $100.3 \pm 5.5^{\mathrm{b}}$ \\
Number of ICM cells & $41.1 \pm 2.2^{\mathrm{a}}$ & $45.9 \pm 2.4^{\mathrm{a}}$ \\
\hline
\end{tabular}

Total numbers of oocytes used, percentage of cleaved zygotes and the proportion of embryos that developed to the blastocyst stage calculated from ten individual culture experiments over the total number of oocytes exposed per group.

Number of blastocyst cells and the ratio of trophectoderm: ICM cells were determined for expanded blastocysts from the control (49 blastocysts) and insulin-treated (42 blastocysts) groups.

${ }^{\mathrm{ab}}$ Insulin significantly increased the number of blastocyst cells as a result of a significant increase in the number of trophectoderm cells, as indicated by different superscripts $(P<0.05)$.

\section{Results}

\section{Effects of insulin on embryonic development}

Insulin significantly increased the rate of cleavage $(P<$ $0.05)$, as well as the proportion of blastocysts $(P<0.05)$ at $186 \mathrm{~h}$ after insemination (Table 2).

Effects of insulin on total number of blastocyst cells and trophectoderm cell : ICM ratio

Blastocysts derived from insulin-supplemented in vitro cultures showed a significant increase in total number of cells $(P<0.01)$ compared with the control group. This increase was due to a significantly higher number 

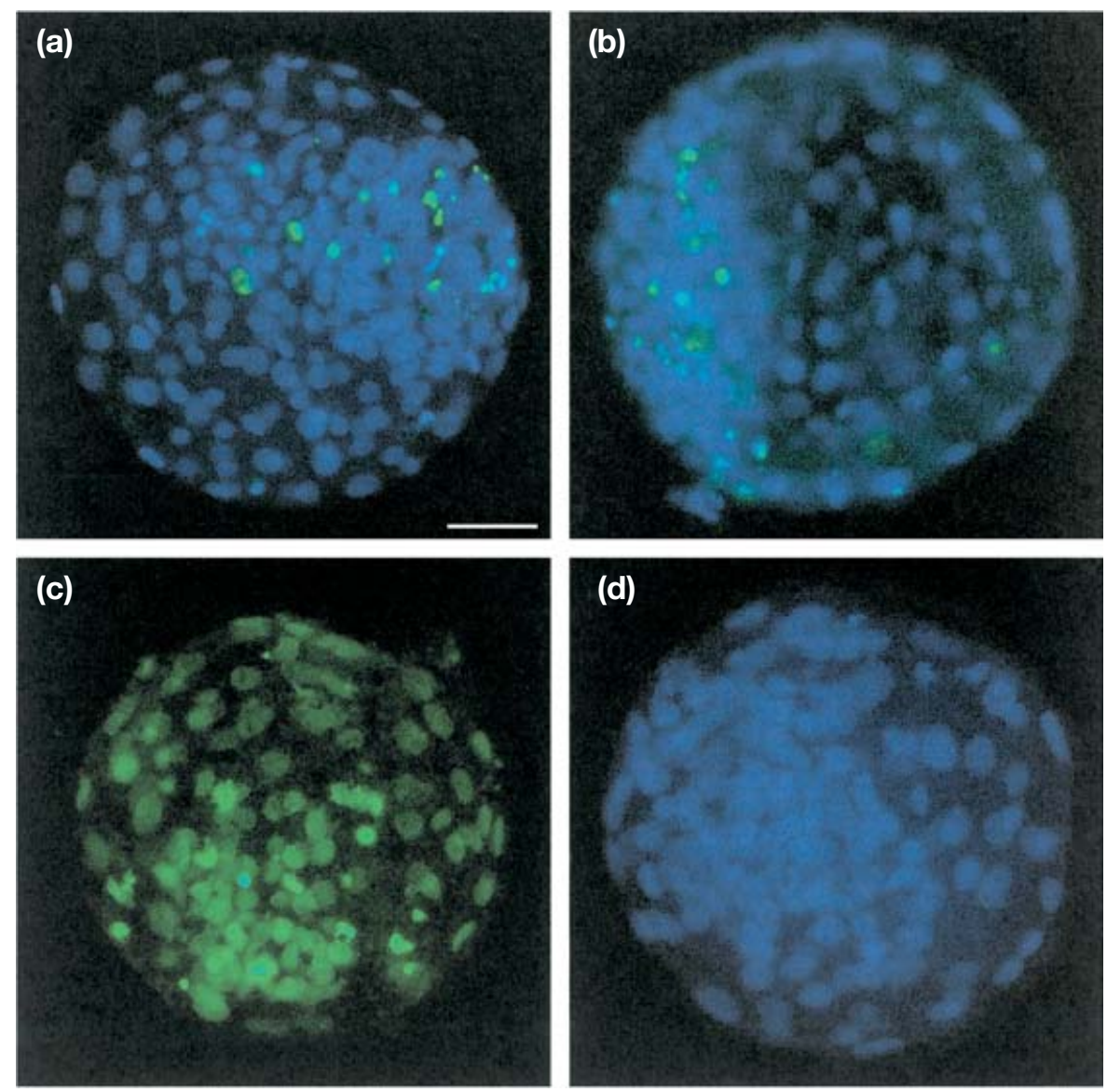

Fig. 1. Representative images of bovine blastocysts at $186 \mathrm{~h}$ after insemination subjected to TUNEL staining to determine apoptosis. Blastocysts representing embryos from (a) the control group, (b) the insulin-treated group, (c) a positive control and (d) a negative control for the TUNEL assay are shown. Green staining indicates fragmented DNA of cells undergoing apoptosis detected by fluorescein isothiocyanate (FITC)-labelled dUTP, whereas intact cell nuclei are stained blue with Hoechst dye. Scale bar represents $50 \mu \mathrm{m}$.

of trophectoderm cells $(P<0.01)$, whereas the ratio of tropectoderm: ICM cells was not different between the groups (Table 2).

\section{Effects of insulin on apoptosis}

TUNEL assay. The TUNEL assay (Fig. 1) revealed that blastocysts grown in the presence of insulin showed a significantly $(P<0.05)$ lower number of apoptotic bodies compared with the control group. Insulin decreased the apoptotic index from $14.8 \pm 0.9$ for controls $(n=53)$ to $12.2 \pm 0.7(n=65)$ in the insulin-treated group. Embryos from six independent culture experiments were compared.

Bax and $B C l-X_{L} m R N A$. The relative amounts of mRNA from insulin-treated and non-treated blastocysts were compared based on standardization using beta-actin mRNA. Insulin supplementation did not affect expression of Bax (1.02 \pm 0.12 -fold $)$ and Bcl- $\mathrm{X}_{\mathrm{L}}(1.00 \pm 0.09$-fold $)$ mRNA compared with control blastocysts.
Effects of insulin on Glut1, 3 and 8 mRNA. The relative amounts of Glut transcripts in blastocysts derived from insulin-supplemented IVP did not differ significantly for Glut1 $(0.96 \pm 0.12$-fold), Glut3 (0.94 \pm 0.12 -fold) and Glut8 $(1.13 \pm 0.08$-fold) compared with the control group.

\section{Discussion}

In the present study, the potential mitogenic and antiapoptotic effects of insulin on development of bovine preimplantation embryos and on expression of Glut isoforms were examined. Although there has been progress in the average efficiency of IVP of bovine embryos over the last few decades, embryos produced in vitro differ from embryos produced in vivo in many aspects (Thompson, 1997; Niemann and Wrenzycki, 2000; Dieleman et al., 2002; Holm et al., 2002). Beneficial effects of various growth factors, such as insulin-IGF-I, 
tranforming growth factor beta (TGF- $\beta$ ), fibroblast growth factor (FGF), platelet-derived growth factor (PDGF), epidermal growth factor (EGF) and growth hormone $(\mathrm{GH})$, on embryo development in vitro have been reported in several species (Kaye, 1997). Growth factors of the insulin-IGF-I family have proliferative, mitogenic and anti-apoptotic effects on embryo development in several species (cow: Matsui et al., 1995a,b; Byrne et al., 2002; mouse: Harvey and Kaye, 1990; rabbit: Herrler et al., 1998; man: Spanos et al., 2000). Mice with gene knockouts for the receptors and ligands of the insulin-IGF-I growth factor family are viable with respect to preimplantation embryo development (for a review, see Nakae et al., 2001). However, these animals are characterized by substantial pre- and postnatal growth retardation (Liu et al., 1993; Kaye and Gardner, 1999).

The present data indicate that insulin can exert mitogenic and anti-apoptotic activities in bovine preimplantation embryos. The results of the present study show that insulin increases rates of cleavage and blastocyst development by 6 and $33 \%$, respectively, as well as the total number of blastocyst cells by $18 \%$. These results are in agreement with the findings of Matsui et al. (1995a), whereas Mihalik et al. (2000a) did not find any significant effects of insulin on blastocyst development. With the exception that the embryos were cultured under reduced $\mathrm{O}_{2}$ concentration using a premixed triple gas $\left(5 \% \mathrm{CO}_{2}\right.$, $5 \% \mathrm{O}_{2}$ and $90 \% \mathrm{~N}_{2}$ ) in the present study, the media composition in both studies (mSOF with either PVA (Matsui et al., 1995a) or BSA (Mihalik et al., 2000)) was similar to the medium used here. Therefore, IVP culture procedures rather than basic culture media composition might be responsible for the different experimental findings.

In the present study, the trophectoderm:ICM ratio was determined to obtain more information about the effect of insulin on blastocyst quality. The increased number of cells in embryos cultured in the presence of insulin was mainly due to an increased number of trophectoderm cells. The trophectoderm: ICM ratio was not significantly different between the two groups. These findings are similar to a study in which bovine embryos were grown in the presence of IGF-I (Prelle et al., 2001). In contrast, in mouse blastocysts cultured with insulin supplementation the higher number of blastocyst cells was selectively caused by a significant increase in ICM cells (Harvey and Kaye, 1990; Smith et al., 1993). The reasons for these divergent findings need further clarification.

The beneficial effect of insulin supplementation on blastocyst development in vitro is further supported by the present findings on the decreased rate of apoptosis. The difference in apoptosis between the groups cultured with and without insulin, represented by the TUNEL index, is comparable with investigations on the effects of IGF-I (Makarevich and Markkula, 2002) or serum
(Byrne et al., 1999) on apoptosis in bovine embryos. In a recent study investigating the mitogenic and antiapoptotic effects of insulin, IGF-I and IGF-II on bovine preimplantation embryos, a significant decrease in the apoptotic index was found at insulin concentrations of $1.8 \mathrm{nmol} \mathrm{I}^{-1}$ (Byrne et al., 2002). However, in contrast to the findings of the present study, no differences in rates of blastocyst development and numbers of cells were noted (Byrne et al., 2002). Further investigations to elucidate the role of insulin and IGF-I on preimplantation development, in particular on number of cells, cell allocation and apoptosis, need to include embryos grown in vivo, thereby allowing a more conclusive view on the effects of insulin-IGF-I observed in IVP systems.

The anti-apoptotic $\mathrm{BCl}-\mathrm{X}_{\mathrm{L}}$ and the death-promotor Bax proteins are known to form homodimers and heterodimers (Sedlak et al., 1995). The shift in the ratio of Bax:Bcl- $\mathrm{X}_{\mathrm{L}}$ at the RNA or protein level determines survival and the degree of apoptosis in various cell systems (Yang and Korsmeyer, 1996; Weinmann et al., 1999; Kim et al., 2001). In the present study, a comparison of the Bax and Bcl- $X_{L}$ mRNA between insulin versus control embryos did not reveal significant differences. This finding might indicate that, as apoptosis in bovine embryos occurs at the 8-16-cell stage (Byrne et al., 1999), a change in mRNA expression for these genes as a result of insulin activity might occur earlier in development, thereby preceding the decrease in DNA fragmentation observed at the blastocyst stage.

No significant changes in the relative amounts of mRNA for Glut1, Glut3 and Glut8 were found between the two groups. The composition of the culture medium significantly affects the expression of glucose transporter mRNA and protein in mouse (Moley et al., 1998; Leppens-Luisier et al., 2001) and bovine (Wrenzycki et al., 1998, 1999) preimplantation embryos. Recent data provide evidence that glucose transporter expression is crucial for development (mouse: Pantaleon et al., 1997; Leppens-Luisier et al., 2001) and is altered in bovine embryos grown in vitro compared with those derived in vivo (Wrenzycki et al., 2001; Lazzari et al., 2002). Depending on the composition of the culture media, changes in Glut1 mRNA expression in bovine embryos were observed at the 8-16-cell (Wrenzycki et al., 1999) and morula stages (Wrenzycki et al., 2001). Differences were less pronounced in blastocysts (Wrenzycki et al., 2001). In a preliminary study investigating the effects of a short-time exposure of expanded day 7 bovine blastocysts to insulin $\left(10 \mu \mathrm{g} \mathrm{ml}^{-1}\right)$ for 1,2 and $4 \mathrm{~h}$, a significant increase in Glut 3 and Glut8 mRNA was found after $1 \mathrm{~h}$ of treatment (R. Augustin, P. Pocar and B. Fischer, unpublished). As a result of these findings, it is concluded that differences in the expression of Glut genes among bovine embryos derived from different IVP procedures (for example, control versus insulin-treated group) might be more pronounced at the earlier stages of development or at shorter periods after exposure to insulin. 
Insulin and IGF-I crossreact with the corresponding receptors. Therefore, the question arises as to whether the observed effects of insulin on bovine embryos were mediated by the insulin or IGF-I receptor. In mouse blastocysts, the effects of insulin are transmitted by both receptors but for different functions. Insulin stimulation of protein synthesis and mitogenesis is mediated by the insulin receptor (Harvey and Kaye, 1988; Harvey and Kaye, 1992), whereas insulin-stimulated glucose uptake in blastocysts is accomplished by the IGF-I receptor (Pantaleon and Kaye, 1996). Recent data for bovine embryos indicate a proliferative, mitogenic and anti-apoptotic activity for IGF-I (Prelle et al., 2001; Makarevich and Markkula, 2002). With respect to the action of insulin, two observations merit attention. First, Matsui et al. (1995a,b) concluded that the action of insulin in bovine embryos is mediated by the IGF-I receptor, as it was blocked by an anti-IGF-I receptor antibody (alphalR-3) (Matsui et al., 1997). Second, the beneficial effects of insulin on development of bovine embryos were observed only when the culture medium was supplemented with glucose (Matsui et al., 1995a,b). As the action of insulin is strongly related to the presence of glucose in the medium (Pantaleon et al., 1997), absence of glucose in the medium might be one of the underlying reasons for the controversial experimental findings in bovine IVP embryos too.

Although the specificity in ligand binding and signalling by insulin and IGF-I receptors is not fully understood (Nakae et al., 2001; Siddle et al., 2001), recent data show that IRS-1 (Amoui et al., 2001) and the PI3-kinase-Akt pathway mediate insulin-specific signalling that results in metabolic (Ueki et al., 1998), as well as mitogenic (Conejo and Lorenzo, 2001) and anti-apoptotic (Barber et al., 2001; lida et al., 2002; Tseng et al., 2002) activity. A key mediator in insulinIGF-I signalling leading to its anti-apoptotic activity and regulation of glucose transport is protein kinase B (PKB or Akt) (Datta et al., 1999; Hajduch et al., 2001; Lawlor and Alessi, 2001). Preliminary data from the authors' laboratory showing that PKB mRNA is expressed in bovine oocytes and preimplantation embryos indicate that bovine embryos may be able to react specifically to insulin via an active insulin-IGF-I signalling pathway.

In conclusion, the present data provide evidence that insulin exerts a mitogenic as well as an anti-apoptotic activity on bovine embryos in vitro resulting in improved blastocyst development and, probably, quality. These activities could not be correlated with changes in the expression of glucose transporters Glut1, Glut3 and Glut8 by insulin.

The authors would like to thank I. Donnay for providing the TUNEL staining protocol for bovine blastocysts. The expert technical assistance of $M$. Kirstein for the in vitro bovine embryo culture procedures is sincerely appreciated.

\section{References}

Alessi DR and Cohen P (1998) Mechanism of activation and function of protein kinase B Current Opinion in Genetics and Development $\mathbf{8}$ 55-62

Amoui M, Craddock BP and Todd Miller W (2001) Differential phosphorylation of IRS-1 by insulin and insulin-like growth factor I receptors in Chinese hamster ovary cells Journal of Endocrinology 171 153-162

Augustin R, Pocar P, Navarrete-Santos A, Wrenzycki C, Gandolfi F, Niemann H and Fischer B (2001) Glucose transporter expression is developmentally regulated in in vitro derived bovine preimplantation embryos Molecular Reproduction and Development 60 370-376

Barber AJ, Nakamura M, Wolpert EB, Reiter CE, Seigel GM, Antonetti DA and Gardner TW (2001) Insulin rescues retinal neurons from apoptosis by a phosphatidylinositol 3-kinase/Akt-mediated mechanism that reduces the activation of caspase-3 Journal of Biological Chemistry 27632 814-32 821

Bavister BD (1989) A consistently successful procedure for in vitro fertilization of golden hamster eggs Gamete Research 23 139-158

Bavister BD, Leibfried ML and Lieberman G (1983) Development of preimplantation embryos of the golden hamster in a defined culture medium Biology of Reproduction 28 235-247

Biggers JD and McGinnis LK (2001) Evidence that glucose is not always an inhibitor of mouse preimplantation development in vitro. Human Reproduction 16 153-163

Brackett BG, Keskintepe L, Simplicio AA and Luvoni GC (1997) Influences of culture components on the development of bovine blastocysts in defined conditions Theriogenology 47274 (Abstract)

Byrne AT, Southgate J, Brison DR and Leese HJ (1999) Analysis of apoptosis in the preimplantation bovine embryo using TUNEL Journal of Reproduction and Fertility 117 97-105

Byrne AT, Southgate J, Brison DR and Leese HJ (2002) Regulation of apoptosis in the bovine blastocyst by insulin and the insulin-like growth factor (IGF) superfamily Molecular Reproduction and Development 62 489-495

Carayannopoulos MO, Chi MM, Cui Y, Pingsterhaus JM, McKnight RA, Mueckler M, Devaskar SU and Moley KH (2000) GLUT8 is a glucose transporter responsible for insulin-stimulated glucose uptake in the blastocyst Proceedings National Academy of Sciences USA 977313 7318

Chatot CL, Lewis-Williams J, Torres I and Ziomek CA (1994) One-minute exposure of 4-cell mouse embryos to glucose overcomes morula block in CZB medium Molecular Reproduction and Development 37 407-412

Conejo R and Lorenzo M (2001) Insulin signaling leading to proliferation, survival, and membrane ruffling in $\mathrm{C} 2 \mathrm{C} 12$ myoblasts Journal of Cellular Physiology 187 96-108

Dalle S, Ricketts W, Imamura T, Vollenweider P and Olefsky JM (2001) Insulin and insulin-like growth factor I receptors utilize different G protein signaling components Journal of Biological Chemistry 276 15 688-15 695

Datta SR, Brunet A and Greenberg ME (1999) Cellular survival: a play in three Akts Genes and Development 13 2905-2927

De Hertogh R, Vanderheyden I, Pampfer S, Robin D and Delcourt J (1992) Maternal insulin treatment improves pre-implantation embryo development in diabetic rats Diabetologia 35 406-408

Diamond MP, Moley KH, Pellicer A, Vaughn WK and DeCherney AH (1989) Effects of streptozotocin- and alloxan-induced diabetes mellitus on mouse follicular and early embryo development Journal of Reproduction and Fertility 86 1-10

Diaz-Cueto L and Gerton GL (2001) The influence of growth factors on the development of preimplantation mammalian embryos Archives of Medical Research 32 619-626

Dieleman SJ, Hendriksen PJ, Viuff D et al. (2002) Effects of in vivo prematuration and in vivo final maturation on developmental capacity and quality of pre-implantation embryos Theriogenology $\mathbf{5 7}$ 5-20

Dorland M, Kruip TAM and van der Donk JA (1992) Assessing day 7 bovine embryo viability by measuring the rate of nutrient uptake Journal of Reproduction and Fertility Abstract Series 9 Abstract 27 
Downward J (1998) Mechanisms and consequences of activation of protein kinase B/Akt Current Opinion in Cell Biology 10 262-267

Dunglison GF and Kaye PL (1993) Insulin regulates protein metabolism in mouse blastocysts Molecular Reproduction and Development 36 $42-48$

Eckert J and Niemann H (1995) In vitro maturation, fertilization and culture to blastocysts of bovine oocytes in protein-free media Theriogenology 43 1211-1225

Gardner HG and Kaye PL (1991) Insulin increases cell numbers and morphological development in mouse pre-implantation embryos in vitro. Reproduction, Fertility and Development 3 79-91

Hagen DR, Prather RS, Sims MM and First NL (1991) Development of onecell porcine embryos to the blastocyst stage in simple media Journal of Animal Science 69 1147-1150

Hajduch E, Litherland GJ and Hundal HS (2001) Protein kinase B (PKB/Akt) - a key regulator of glucose transport? FEBS Letters 492 199-203

Hardy K (1999) Apoptosis in the human embryo Reviews of Reproduction 4 125-134

Harvey MB and Kaye PL (1988) Insulin stimulates protein synthesis in compacted mouse embryos Endocrinology 122 1182-1184

Harvey MB and Kaye PL (1990) Insulin increases the cell number of the inner cell mass and stimulates morphological development of mouse blastocysts in vitro. Development 110 963-967

Harvey MB and Kaye PL (1991) Mouse blastocysts respond metabolically to short-term stimulation by insulin and IGF-I through the insulin receptor Molecular Reproduction and Development 29 253-258

Harvey MB and Kaye PL (1992) Mediation of the actions of insulin and insulin-like growth factor-I on preimplantation mouse embryos in vitro. Molecular Reproduction and Development 33 270-275

Herrler A, Krusche CA and Beier HM (1998) Insulin and insulin-like growth factor-I promote rabbit blastocyst development and prevent apoptosis Biology of Reproduction 59 1302-1310

Heyner S (1997) Growth factors in preimplantation development: role of insulin and insulin-like growth factors Early Pregnancy 3 153-163

Holm P, Booth PJ and Callesen H (2002) Kinetics of early in vitro development of bovine in vivo- and in vitro-derived zygotes produced and/or cultured in chemically defined or serum-containing media Reproduction 123 553-565

lida KT, Suzuki H, Sone H, Shimano H, Toyoshima H, Yatoh S, Asano T, Okuda Y and Yamada N (2002) Insulin inhibits apoptosis of macrophage cell line, THP-1 cells, via phosphatidylinositol-3-kinase-dependent pathway Arteriosclerosis, Thrombosis and Vascular Biology 22 380-386

Iwata H, Akamatsu S, Minami N and Yamada M (1998) Effects of antioxidants on the development of bovine IVM/IVF embryos in various concentrations of glucose Theriogenology 50 365-375

Javed MH and Wright RW (1991) Determination of pentose phosphate and Embden-Meyerhof pathway activities in bovine embryos Theriogenology 335 1029-1037

Joost HG and Thorens B (2001) The extended GLUT-family of sugar/polyol transport facilitators: nomenclature, sequence characteristics, and potential function of its novel members (review) Molecular Membrane Biology 18 247-256

Joost HG, Bell GI, Best JD et al. (2002) Nomenclature of the GLUT/SLC2A family of sugar/polyol transport facilitators American Journal of Physiology, Endocrinology and Metabolism 282 E974-976

Kan O, Baldwin SA and Whetton AD (1994) Apoptosis is regulated by the rate of glucose transport in an interleukin 3 dependent cell line Journal of Experimental Medicine 180 917-923

Kaye PL (1997) Preimplantation growth factor physiology Reviews of Reproduction 2 121-127

Kaye PL and Gardner HG (1999) Preimplantation access to maternal insulin and albumin increases fetal growth rate in mice Human Reproduction 14 3052-3059

Kaye PL and Harvey MB (1995) The role of growth factors in preimplantation development Progress in Growth Factor Research 6 1-24

Khurana NK and Niemann H (2000) Energy metabolism in preimplantation bovine embryos derived in vitro or in vivo. Biology of Reproduction 62 $847-856$
Kim HJ, Mun JY, Chun YJ, Choi KH and Kim MY (2001) Bax-dependent apoptosis induced by ceramide in HL-60 cells FEBS Letters 505264 268

Lawlor MA and Alessi DR (2001) PKB/Akt: a key mediator of cell proliferation, survival and insulin responses? Journal of Cell Science 114 2903-2910

Lazzari G, Wrenzycki C, Herrmann D, Duchi R, Kruip T, Niemann H and Galli C (2002) Cellular and molecular deviations in bovine in vitroproduced embryos are related to the large offspring syndrome Biology of Reproduction 67 767-775

Leppens-Luisier G, Urner F and Sakkas D (2001) Facilitated glucose transporters play a crucial role throughout mouse preimplantation embryo development Human Reproduction 16 1229-1236

Leunda-Casi A, Genicot G, Donnay I, Pampfer S and De Hertogh R (2002) Increased cell death in mouse blastocysts exposed to high D-glucose in vitro: implications of an oxidative stress and alterations in glucose metabolism Diabetologia 45 571-579

Lewis AM, Kaye PL, Lising R and Cameron RD (1992) Stimulation of protein synthesis and expansion of pig blastocysts by insulin in vitro. Reproduction, Fertility and Development 4 119-123

Liu JP, Baker J, Perkins AS, Robertson EJ and Efstratiadis A (1993) Mice carrying null mutations of the genes encoding insulin-like growth factor I (IGF-I) and type 1 IGF receptor (IGF1R) Cell 75 59-72

Lonergan P, Gutierrez-Adan A, Pintado B, Fair T, Ward F, Fuente JD and Boland M (2000) Relationship between time of first cleavage and the expression of IGF-I growth factor, its receptor, and two housekeeping genes in bovine two-cell embryos and blastocysts produced in vitro. Molecular Reproduction and Development 57 146-152

McGinnis LK and Youngs CR (1992) In vitro development of ovine embryos in CZB medium Theriogenology 37 559-569

McGowan KM, Long SD and Pekala PH (1995) Glucose transporter gene expression: regulation of transcription and mRNA stability Pharmacology and Therapeutics 66 465-505

Makarevich AV and Markkula M (2002) Apoptosis and cell proliferation potential of bovine embryos stimulated with insulin-like growth factor I during in vitro maturation and culture Biology of Reproduction 66 386-392

Martin KL and Leese HJ (1995) Role of glucose in mouse preimplantation embryo development Molecular Reproduction and Development 40 436-443

Matsui M, Takahashi Y, Hishinuma M and Kanagawa H (1995a) Stimulatory effects of insulin on the development of bovine embryos fertilized in vitro. Journal of Veterinary Medical Science 57 331-336

Matsui M, Takahashi Y, Hishinuma M and Kanagawa H (1995b) Insulin and insulin-like growth factor-I (IGF-I) stimulate the development of bovine embryos fertilized in vitro. Journal of Veterinary Medical Science $\mathbf{5 7}$ 1109-1111

Matsui M, Takahashi Y, Hishinuma M and Kanagawa H (1997) Stimulation of the development of bovine embryos by insulin and insulin-like growth factor-I (IGF-I) is mediated through the IGF-I receptor Theriogenology $\mathbf{4 8}$ 605-616

Mihalik J, Rehak P and Koppel J (2000) The influence of insulin on the in vitro development of mouse and bovine embryos Physiological Research 49 347-354

Moley KH, Vaughn WK, DeCherney AH and Diamond MP (1991) Effect of diabetes mellitus on mouse pre-implantation embryo development Journal of Reproduction and Fertility 93 325-332

Moley KH, Chi MM, Knudson CM, Korsmeyer SJ and Mueckler MM (1998a) Hyperglycemia induces apoptosis in pre-implantation embryos through cell death effector pathways Nature Medicine 4 1421-1424

Moley KH, Chi MM and Mueckler MM (1998b) Maternal hyperglycemia alters glucose transport and utilization in mouse preimplantation embryos American Journal of Physiology 275 E38-47

Nakae J, Kido Y and Accili D (2001) Distinct and overlapping functions of insulin and IGF-I receptors Endocrinological Reviews 22 818-835

Navarrete Santos A, Augustin R, Lazzari G, Galli C, Sreenan JM and Fischer B (2000) The insulin-dependent glucose transporter isoform 4 is expressed in bovine blastocysts Biochemical and Biophysical Research Communications 271 753-760 
Niemann H and Wrenzycki C (2000) Alterations of expression of developmentally important genes in preimplantation bovine embryos by in vitro culture conditions: implications for subsequent development Theriogenology 53 21-34

Pampfer S (2000) Peri-implantation embryopathy induced by maternal diabetes Journal of Reproduction and Fertility 55 129-139

Pantaleon M and Kaye PL (1996) IGF-I and insulin regulate glucose transport in mouse blastocysts via IGF-I receptor Molecular Reproduction and Development 44 71-76

Pantaleon M and Kaye PL (1998) Glucose transporters in preimplantation development Reviews of Reproduction 3 77-81

Pantaleon M, Harvey MB, Pascoe WS, James DE and Kaye PL (1997) Glucose transporter GLUT3: ontogeny, targeting, and role in the mouse blastocyst Proceedings National Academy of Sciences USA 94 3795-3800

Pinto AB, Carayannopoulos MO, Hoehn A, Dowd L and Moley KH (2002) Glucose transporter 8 expression and translocation are critical for murine blastocyst survival Biology of Reproduction 66 1729-1733

Prelle K, Stojkovic M, Boxhammer K, Motlik J, Ewald D, Arnold GJ and Wolf E (2001) Insulin-like growth factor I (IGF-I) and long R(3)IGF-I differently affect development and messenger ribonucleic acid abundance for IGFbinding proteins and type I IGF receptors in in vitro produced bovine embryos Endocrinology 142 1309-1316

Rao LV, Wikarczuk ML and Heyner S (1990) Functional roles of insulin and insulin-like growth factors in preimplantation mouse embryo development in vitro. Cellular and Developmental Biology 26 10431048

Renard JP, Philippon A and Menezo Y (1980) In vitro uptake of glucose by bovine blastocysts Journal of Reproduction and Fertility $\mathbf{5 8}$ 161-164

Robert C, McGraw S, Massicotte L, Pravetoni M, Gandolfi F and Sirard MA (2002) Quantification of housekeeping transcript levels during the development of bovine preimplantation embryos Biology of Reproduction 67 1465-1472

Saltiel AR and Kahn CR (2001) Insulin signalling and the regulation of glucose and lipid metabolism Nature $\mathbf{4 1 4}$ 799-806

Schultz GA, Hogan A, Watson AJ, Smith RM and Heyner S (1992) Insulin, insulin-like growth factors and glucose transporters: temporal patterns of gene expression in early murine and bovine embryos Reproduction, Fertility and Development 4 361-371

Sedlak TW, Oltvai ZN, Yang E, Wang K, Boise LH, Thompson CB and Korsmeyer SJ (1995) Multiple BCl-2 family members demonstrate selective dimerizations with Bax Proceedings National Academy of Sciences USA 92 7834-7838

Siddle K, Urso B, Niesler CA, Cope DL, Molina L, Surinya KH and Soos MA (2001) Specificity in ligand binding and intracellular signalling by insulin and insulin-like growth factor receptors Biochemical Society Transactions 29 513-525

Smith RM, Garside WT, Aghayan M, Shi CZ, Shah N, Jarett L and Heyner S (1993) Mouse preimplantation embryos exhibit receptor-mediated binding and transcytosis of maternal insulin-like growth factor I Biology of Reproduction 49 1-12

Spanos S, Becker DL, Winston RM and Hardy K (2000) Anti-apoptotic action of insulin-like growth factor-I during human preimplantation embryo development Biology of Reproduction 63 1413-1420
Summers SA, Yin VP, Whiteman EL, Garza LA, Cho H, Tuttle RL and Birnbaum MJ (1999) Signaling pathways mediating insulin-stimulated glucose transport Annals of the New York Academy of Science 892 169-186

Tervit HR, Whittingham DG and Rowson LE (1972) Successful culture in vitro of sheep and cattle ova Journal of Reproduction and Fertility 30 493-497

Thompson JG (1997) Comparison between in vivo-derived and in vitroproduced pre-elongation embryos from domestic ruminants Reproduction, Fertility and Development 9 341-354

Thouas G, Natasha Korfiatis N, French A, Jones G and Trounson A (2001) Simplified chemically defined technique for differential staining of mouse and bovine blastocysts Reproductive BioMedicine Online 3 25-29

Tseng YH, Ueki K, Kriauciunas KM and Kahn CR (2002) Differential roles of insulin receptor substrates in the anti-apoptotic function of insulinlike growth factor-I and insulin Journal of Biological Chemistry 277 $31601-31611$

Ueki K, Yamamoto-Honda R, Kaburagi Y et al. (1998) Potential role of protein kinase B in insulin-induced glucose transport, glycogen synthesis, and protein synthesis Journal of Biological Chemistry 273 5315-5322

Weinmann P, Gaehtgens P and Walzog B (1999) Bcl-XI- and Bax-alphamediated regulation of apoptosis of human neutrophils via caspase-3 Blood 93 3106-3115

Winger QA, de los Rios P, Han VK, Armstrong DT, Hill DJ and Watson AJ (1997) Bovine oviductal and embryonic insulin-like growth factor binding proteins: possible regulators of "embryotrophic" insulin-like growth factor circuits Biology of Reproduction 56 1415-1423

Wrenzycki C, Herrmann D, Carnwath JW and Niemann H (1998) Expression of RNA from developmentally important genes in preimplantation bovine embryos produced in TCM supplemented with BSA Journal of Reproduction and Fertility 112 387-398

Wrenzycki C, Herrmann D, Carnwath JW and Niemann H (1999) Alterations in the relative abundance of gene transcripts in preimplantation bovine embryos cultured in medium supplemented with either serum or PVA Molecular Reproduction and Development 53 8-18

Wrenzycki C, Herrmann D, Keskintepe L, Martins A, Jr, Sirisathien S, Brackett B and Niemann H (2001) Effects of culture system and protein supplementation on mRNA expression in pre-implantation bovine embryos Human Reproduction 16 893-901

Yang E and Korsmeyer SJ (1996) Molecular thanatopsis: a discourse on the BCL2 family and cell death Blood 88 386-401

Yaseen MA, Wrenzycki C, Herrmann D, Carnwath JW and Niemann H (2001) Changes in the relative abundance of mRNA transcripts for insulin-like growth factor (IGF-I and IGF-II) ligands and their receptors (IGF-IR/IGF-IIR) in preimplantation bovine embryos derived from different in vitro systems Reproduction 122 601-610

Received 14 January 2003.

First decision 18 February 2003.

Revised manuscript received 28 March 2003.

Accepted 31 March 2003. 